\title{
Teknologi Rekayasa \& Rancang Bangun Yang Terintegrasi
}

\author{
Agus Rusyana Hoetman ${ }^{1 a)}$ \\ ${ }^{1}$ Balai Besar Teknologi Konversi Energi-BPPT \\ Serpong, Tangerang Selatan-Banten, Indonesia \\ a)arhoetman75@gmail.com (corresponding author)
}

\begin{abstract}
Abstrak
Perkembangan Industri, khususnya industri rancang bangun \& rekayasa serta industri manufaktur nasional harus menjadi perhatian kita. Dengan berkembangnya industri tersebut mencerminkan kekuatan penguasaan teknologi yang akan berdampak kepada kemajuan peningkatan produk dalam negeri (Tingkat Kandungan Dalam Negeri/TKDN). Program pembangunan nasional, industrialisasinya sebagian besar masih dikuasai oleh industri asing, hal tersebut selain dikarenakan pendanaannya sebagian besar masih dari dana pinjaman, yang didalamnya terdapat "keharusan" memakai teknologi dan pengadaaan barang dari pihak si pemberi pinjaman, juga kemungkinan karena industri nasional masih lemah dalam menciptakan kualitas "konsepsi desain" yang efisien dan terintegrasi, sehingga sistem dan peralatan yang ditawarkan kurang kompetitif. Bidang teknologi proses yang dipadukan dengan teknologi Computer Aided Design \& Drafting (CADD) dan Computer Aided Engineering (CAE) serta konsep modularisasi merupakan konseptual teknologi dari program yang efisien dan terintegrasi. Konsepsi ini telah dibuktikan menghemat biaya pembangunan sekitar 15 hingga $30 \%$. Hal ini yang akan dibahas dalam tulisan singkat ini.
\end{abstract}

Kata kunci: computer aided engineering, rekayasa rancang bangun, modularisasi

\section{Pendahuluan.}

Perkembangan industri, khususnya industri rancang bangun \& rekayasa serta industri manufaktur nasional pada awal tahun sembilan puluhan bisa dikatakan cukup lumayan, meskipun apabila dilihat secara fundamental perkembangan tersebut masih bersifat semu. Hal tersebut dapat dilihat dari keterlibatan industri nasional dalam pembangunan proyek-proyek besar pada saat itu, yang belum mampu menjadi tuan rumah di negerinya sendiri. Beberapa industri hanya mampu bertindak sebagai tukang jahit eceran, dimana keadaannya tidak mempunyai daya tawar/saing yang signifikan untuk mendapatkan porsi yang wajar sebagai industri tuan rumah. Beberapa kendala yang dialamai industri pada waktu itu, selain hal umum yang didikte oleh syaratsyarat finansial, juga kendala khusus kesiapan teknis dibidang teknologi rekayasa dan rancang bangun yang belum siap secara mandiri dan terintegrasi.

Harus diakui bahwa karena finansial untuk pembangunan suatu proyek sebagian besar masih dari dana pinjaman, yang didalamnya kadang ada unsur "keharusan" melibatkan si pemberi pinjaman, baik dalam pengadaan barang ataupun teknologi, sehingga sedikit banyak berpengaruh kepada strategi pengaturan proyek, dan keleluasaan menggunakan teknologi dan produk lokal. Mungkin dikarenakan hal tersebut, kesiapan industri nasional pun dalam teknologi rekayasa rancang bangun, yang menjadi dasar daya tawar, juga belum kuat. Pada umumnya kemampuan dibidang teknologi proses yang merupakan konseptual teknologi dari proyek, belum banyak dikuasai. Teknologi proses atau teknologi konseptual ini, beserta paten-patennya, sebagian besar masih dikuasai oleh perusahaan asing. Padahal pada awal pertimbangan konseptual inilah, spesifikasi peralatan dan material mulai ditentukan. Sehingga tidak aneh kalau pada akhirnya, baik peralatan maupun material yang disyaratkan akan masih mengacu kepada sipenguasa teknologi dan atau sipemberi dana.

Disisi lebih hilir, yaitu dibidang desain detil, hanya beberapa industri nasional yang mampu secara mandiri, selebihnya masih mengandalkan ahli asing. Kemampuan dalam bidang desain detil secara lokal, sedikit banyak akan memberikan peluang kepada industri manufaktur dan konstruksi lokal untuk lebih banyak berkiprah dalam suatu proyek. Mengingat tahapan kendala yang dimulai dari pendanaan serta teknologi konseptual yang masih didominasi asing, mungkin sementara ini, pengkajian dan pengembangan di bidang desain detil yang patut ditajamkan serta dikuasai secara mandiri dan terintegrasi, dan sejalan dengan itu, patut diberikan kesempatan kepada lembaga penelitian swasta dan pemerintah untuk memulai mengkaji danmengembangkan konsep-konsep teknologi proses yang diprioritaskan. Tulisan ini akan mengetengahkan perkembangan dan keuntungan menggunakan konsep modeling tiga dimensi (3-D modeling) dalam melakukan tahapan desain detil secara terintegrasi.

\section{Kondisi Aktifitas Rekayasa Rancang Bangun Masih Manual}

Gambaran aktifitas rekayasa rancang bangun dalam suatu proyek secara umum, yang menggambarkan suatu aktifitas aliran informasi dan otoritas tiap-tiap pelaku kegiatan dapat disederhanakan seperti ditunjukkan pada gambar 1 . 


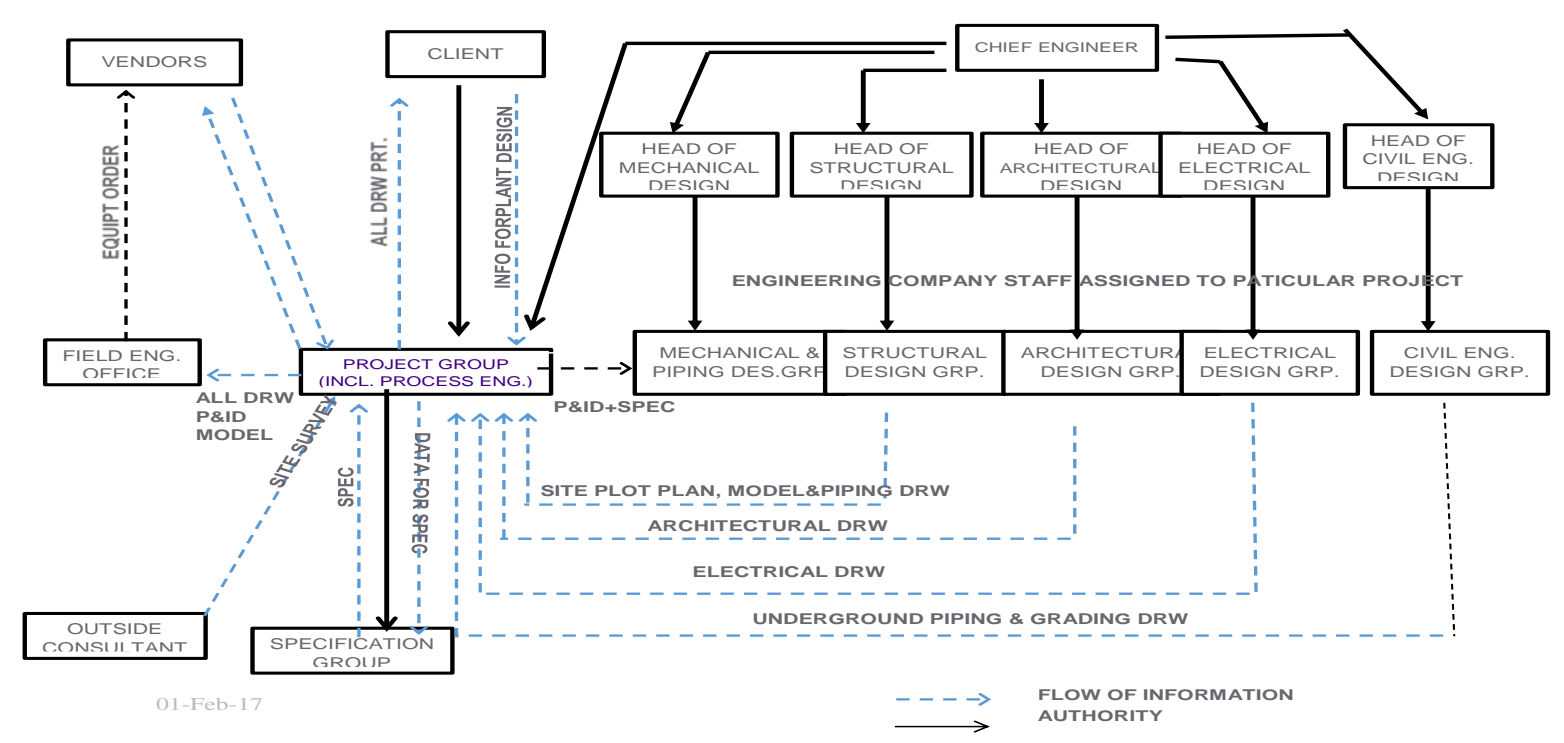

Gambar 1. Diagram organisasi proyek serta otoritas dan aliran informasinya [2].

Project Group dimana dalam hal ini didalamnya termasuk kelompok process engineer, merupakan posisi sentral dari kegiatan rekayasa rancang bangun. Semua permintaan atau keinginan client ditampung oleh kelompok ini. Kemudian dalam melakukan kegiatannya, kelompok ini berkoordinasi dengan kelompok-kelompok specification, vendors, field engineer, konsultan luar apabila diperlukan dan kemudian chief engineer nya akan mengkoordinasikan kegiatan desain detil. Pada kegiatan desain detil, kelompok process engineer akan memberikan informasi yang diperlukan berupa spesifikasi proyek (System Specification Document; SSD), dan Piping \& Instrumentation Diagram (P\&ID) kepada chief engineer untuk kemudian diterjemahkan oleh kelompok desain detil, yang terdiri dari kelompok-kelompok mekanikal (mechanical), perpipaan (piping), sipil (civil), struktur (structure), dan elektrikal (electrical). Setelah proses desain detil tersebut selesai diintegrasikan menjadi suatu hasil rekayasa rancang bangun kemudian project group akan menyerahkannya kepada client.

Tahapan Alur informasi pada proses desain detil secara rinci adalah sebagai berikut:

- Formulasi pembuatan Poses Flow Diagram (PFD), yang kemudian diwujudkan menjadi P\&ID dan SSD, dilakukan oleh kelompok proses.

- Kelompok tesebut bersama-sama kelompok desain Mekanikal dan piping kemudian menterjemahkan -nya menjadi suatu gambaran umum tata letak (General Arrangement).

- Kemudian kelompok desain sipil \& struktur melakukan desain awalnya, setelah ada informasi tentang spesifikasi awal peralatan (Equipments).
- Pada waktu desain struktur telah memberikan global rancangannya, kelompok desain perpipaan sudah dapat melakukan kegiatannya membuat desain piping layout.

- Setelah tahapan diatas diselesaikan, kemudian dimulailah tahapan analisis kekuatan dan tegangan secara rinci pada struktur dan perpipaan. Perubahahan desain sangat mungkin terjadi, baik pada struktur, perpipaan, tataletak alat dll, dan jika itu terjadi maka akan dilakukan revisi terhadap desain tadi sampai dengan dinyatakan benar. Kegiatan semacam ini biasanya dilakukan berulang, dan tiap kali iterasi masih dimungkinkan perubahan desain.

- Tahapan terakhir adalah pembuatan gambargambar detil untuk struktur, isometrik \& spool untuk perpipaan serta membuat daftar material (List of Materials/Bill of Materials) untuk keperluan procurement dan perhitungan biaya.

Setiap revisi pada tiap tahap atau iterasi dimungkinkan terjadi kesalahan baik kecil ataupun revisi total. Hal ini yang menjadikan kendala besar apabila desain/penggambaran dilakukan secara manual.

\section{Pengembangan Metode Desain Engineering}

\section{A. Teknologi Computer Aided Design \& Drafting dan Computer Aided Engineering [1]}

Perkembangan teknologi dibidang Computer Aided Design \& Drafting (CADD) dan Computer Aided Engineering (CAE) dalam 10 tahun terakhir ini cukup pesat. Dimulai dari perkembangan 2Dimension (2D) Computer Aided Design dibidang desain yang bertitik berat kepada desain grafis hingga kombinasi desain grafis dan data (masih 2D) untuk 
Process Flow Diagram (PFD), Piping \& Instrumentation Diagram (P\&ID), Instrument Data Manager (IDM) dan Electrical Data Management (EDM). Selain itu perkembangan-nya dibidang modeling, yang semula hanya mampu untuk menggambar sederhana secara 2 Dimensi, pada saat ini sudah mampu digunakan untuk mendesain secara ruang (3 Dimensi/3D) yang menggabungkan grafik dan data secara pintar. Bersamaan dengan itu kemampuan CAE pun berkembang, menjadikan proses perhitungan/ komputasi engineering dapat berintegrasi dengan sistem CADD.

Dengan menggunakan kemajuan teknologi dibidang CADD dan CAE yaitu modeling yang diintegrasikan dengan komputasi engineering, kemajuan dibidang desain detil pun serta merta mengalami kemajuan yang sangat pesat, meninggalkan teknologi lama yang masih manual ataupun yang semi manual.

Namun harus tetap diingat bahwa komputer hanyalah alat, bahwa otomatisasi desain, drafting dan rekayasa proses menggunakan komputer hanyalah cara mempercepat proses dan akurasi, yang menentukan hasil dari keluaran adalah tetap masukan yang benar, yang dilakukan oleh manusia dibelakangnya. Jadi tetap yang penting adalah Orang yang mempunyai skill yang berada dibelakang itu semua yang menentukan akurasi hasil.

\section{B. Rekayasa Rancang bangun terintegrasi [4]}

Kegiatan rekayasa \& rancang bangun pada saat ini sudah beralih dari sistem manual ke sistem otomatis mengguna-kan fasilitas CADD dan CAE. Seperti dijelaskan diatas bahwa teknologi komputer telah begitu pesat, sehingga memudahkan dan mempercepat proses pekerjaan rekayasa dan rancang bangun, bahkan dengan menggunakan teknologi $3 D$ modeling yang di integrasikan dengan kemampuan CAE, menghasilkan suatu terobosan, yang selain dapat mempercepat proses rekayasa rancang bangun, juga menghasilkan produk yang lebih akurat dan berdaya guna lebih.

Dengan menggunakan teknologi yang terintegrasi ini proses desain seperti yang telah dijelaskan pada awal tulisan akan lebih sederhana, seperti digambarkan pada gambar 3 .

Awal kegiatan pada waktu pendefinisian proyek, dan pembuatan perhitungan proses, Proses Flow Diagram (PFD), Piping \& Instrumentation Diagram (P\&ID), serta pembuatan System Specification Document (SSD), relatif sama, malah ada kegiatan tambahan berupa aktifitas set up data base untuk mendefinisikan spesifikasi tiap garis pipa, dan peralatan lainnya. Dengan dibuat data base tersebut, maka P\&ID menjadi informatif dan pintar.

Setelah dibuat gambar General Arrangement nya, lalu bersama-sama dengan P\&ID didistribusikan ke kelompok-kelompok desain seperti halnya pada desain manual. Perbedaan pada konsep desain terintegrasi dan manual pada tahap ini adalah bahwa tiap kelompok desain dapat memulai pekerjaannya tanpa harus saling menunggu secara berurutan. Tiap kelompok desain dapat melihat dan menjadikan kelompok lain sebagai referensi untuk keperluan desainnya. Begitu pula kelompok analisis yang akan melakukan analisis kekuatan dan tegangan pada struktur dan perpipaan, dapat secara bertahap melakukan kegiatannya. Yang cukup efisien dan menghasilkan akurasi tinggi yaitu adanya proses nput/output yang dilakukan oleh kelompok analisis, yaitu dengan mentransfer data elektronik langsung dari desain awal struktur dan perpipaan. Hal ini mengurangi kesalahan input yang bisanya terjadi akibat ketidak telitian orang (human error).

Tahapan selanjutnya adalah melakukan desain detil pada struktur baja dan perpipaan, yang kemudian secara otomatis produk isometrik dan bill of material yang di lengkapi dengan informasi pipe cut length dapat di print out. Diagram proses rekayasa \& rancang bangun secara lengkap dapat dilihat pada gambar 4 .

\section{Modularisasi}

Modularisasi adalah suatu konsep desain secara modular. Secara definisi dapat dikatakan bahwa suatu modul adalah suatu assembly dari beberapa komponen termasuk perpipaan, peralatan mekanik, listrik dan sistem kendali/ instrumentasi dan struktur secara terintegrasi.

Kriteria umum dalam mendesain modul biasanya sbb:

- Memenuhi syarat keperluan konstruksi

- Memenuhi syarat keamanan, termasuk keamanan pada waktu handling dan transportasi

- Ukuran modul biasanya di sesuaikan dengan kemampuan transportasi yang ada

- Memenuhi persyaratan untuk inspeksi dan maintenance

- Memenuhi standard industri yang berlaku.

Dengan konsep modular ini diharapkan mendapatkan keuntungan pada waktu konstruksi, dan mempercepat pada waktu pabrikasi. Prediksi keuntungan pada waktu konstruksi diperkirakan sekitar 15 sampai $30 \%$ dari total biaya konstuksi, hal ini disebabkan lebih pendeknya masa konstruksi di lapangan [3]. Hasil desain suatu modul ditunjukkan pada gambar 2 [3].

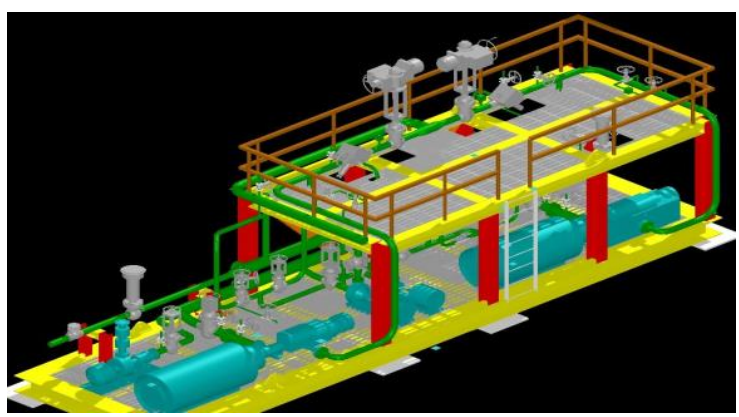

Gambar 2. Desain Modul 


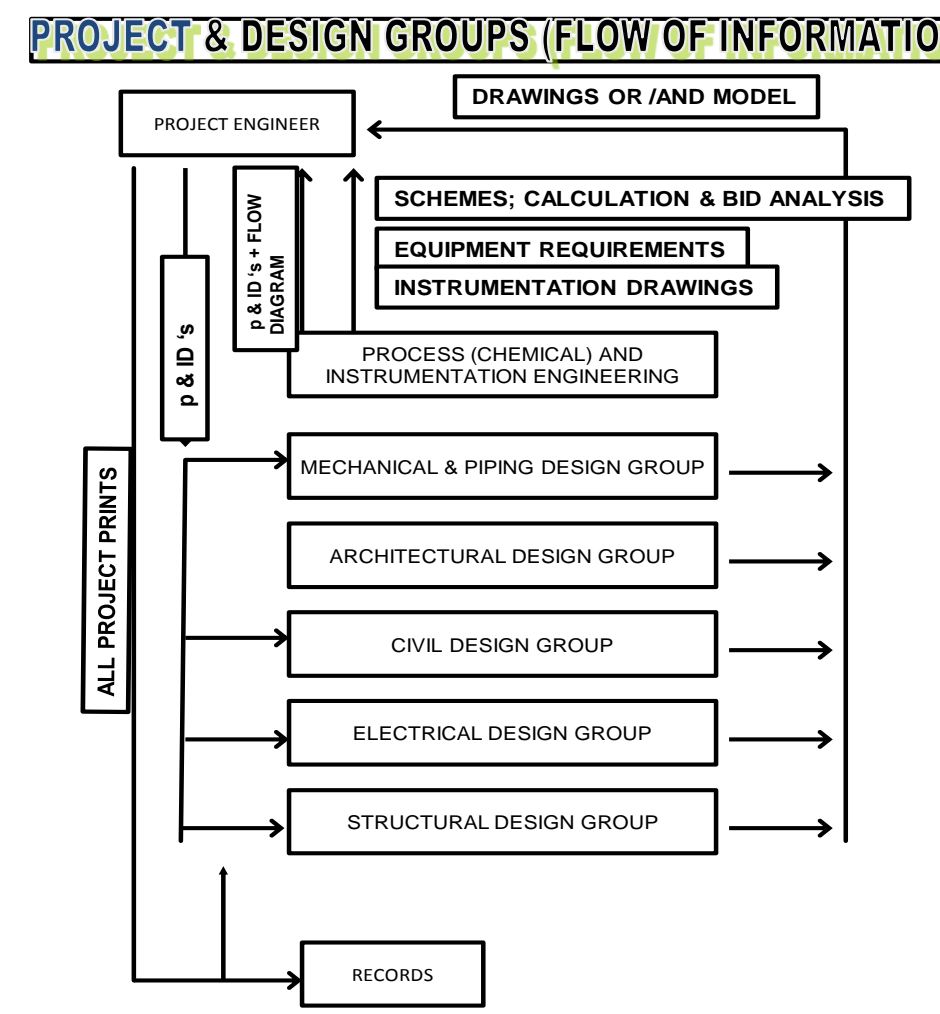

Gambar 3. Diagram alir informasi pada kegiatan rekayasa rancang bangun [1]

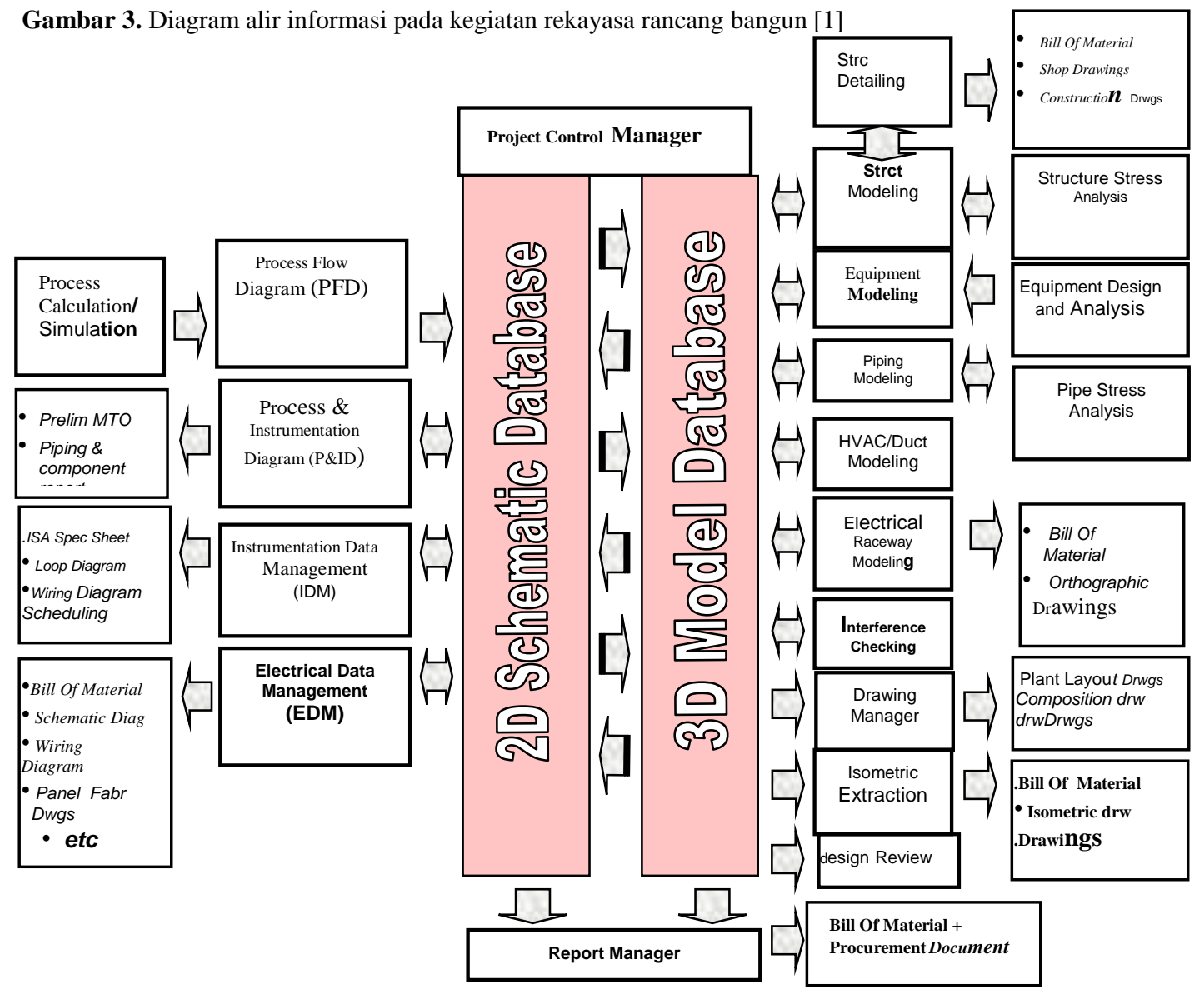

Gambar 4. Diagram proses rekayasa rancang bangun terintegrasi dengan system Plant Design 


\section{Kesimpulan}

Penguasaan konsep teknologi rekayasa rancang bangun menggunakan model 3 dimensi yang diintegrasikan dengan penguasaan $\mathrm{CAE}$ dan desain modularisasi, selain memberikan akurasi lebih tinggi pada hasil desain, mudah dilakukan perubahan, mudah untuk dikomunikasikan lewat transportasi elektronik, juga penurunan man hour desain. Selain itu yang lebih penting adalah memberikan dampak yang cukup banyak dalam perencanaan, procurement, pembangunan, pengoperasian, pengelolaan dan pengembangan proyek dan decomissioning. Hal ini dikarenakan dengan menggunakan konsep ini, data desain ditata dalam database, sehingga hasil desain akan merupakan produk yang pintar dan datanya dapat dipakai untuk keperluan selama umur proyek. Disisi lain diperlukan adanya investasi tambahan yang cukup tinggi untuk perangkat lunak dan keras, ketergantungan terhadap vendor perangkat lunak serta investasi meningkatkan kualitas sumber daya manusia yang harus lebih tinggi.

\section{REFERENSI}

[1] Engineering Center Design Guide Book, Pusat Enjiniring-BPPT, Jakarta, 2000

[2] Paul R. Smith, Thomas J. Van Laan, Piping Systems Design Engineering, Mc. Graw-Hill Book Company, New York, NY 10020

[3] Westinghouse Electric Corporation, Modular Construction, USA, 1994

[4] Agus R. Hoetman, Project Manual Design Book, Pusat Enjiniring-BPPT, Jakarta versi 2005. 